\title{
Intraspinal Transplantation of Autologous Neurogenically-Induced Bone Marrow-Derived Mesenchymal Stem Cells in the Treatment of Paraplegic Dogs without Deep Pain Perception Secondary to Intervertebral Disk Disease
}

\author{
Intervertebral Disk Hastalığı Sonucu Parapleji Gelişen ve Derin \\ Ağr Duyusu Olmayan Köpeklerin Tedavisinde Intraspinal Otolog \\ Nörona Yönlendirilmiş Kemik İliği Kökenli Mezenkimal Kök Hücre \\ Transplantasyonu
}

Omer BESALTI ${ }^{1}$, Pinar CAN ${ }^{1}$, Eylul AKPINAR ${ }^{1}$, Zeynep AKTAS ${ }^{2}$, Ayse Eser ELCIN ${ }^{2}$, Yasar Murat ELCIN ${ }^{2}$

${ }_{1}^{1}$ Ankara University, Faculty of Veterinary Medicine, Department of Surgery, Ankara, Turkey

${ }^{2}$ Ankara University, Faculty of Science, and Ankara University Stem Cell Institute, Tissue Engineering, Biomaterials and Nanobiotechnology Laboratory, Ankara, Turkey

Corresponding Author: Omer BESALTI / E-mail: besalti@hotmail.com

\section{ABSTRACT}

AIM: To investigate the effects of neurogenically-induced autologous bone marrow-derived mesenchymal stem cells (NIBM-MSCS) in paraplegic dogs without deep pain perception (DPP) secondary to intervertebral disk disease (IVDD).

MATERIAL and METHODS: Seven dogs which could not be improved neurologically with conventional treatment modalities were included in the study. All dogs were diagnosed by magnetic resonance imaging and surgically treated. Each dog received two times a suspension of autologous 5.0 $10^{6} \mathrm{NIBM}-\mathrm{MSC}$, which were positive to CNPase and MAP-2, as well as to GFAP and beta III tubulin into the spinal cord through the hemilaminectomy defect percutaneously, with a 21-day interval.

RESULTS: Two months after cell transplantation, there were no changes except for 1 gait score improvement for 1 of the cases. At the 4th month, gait score had improved 1 score in 5 cases, and one score progress was recorded in proprioception and nociception in 1 case. In eight months-followed up 4 cases were evaluated by the same parameter; gait score had improved in 3 cases, and propriception improved in 2 cases, and nociception improved in 3 cases.

CONCLUSION: Our findings suggest that utility of autologous NIBM-MSCs for cases with poor prognosis after IVDD can be a promising approach.

KEYWORDS: Spinal cord injury, Dog, Mesenchymal stem cells (MSCs), Intervertebral disk disease

Öz

AMAÇ: İntervertebral disk hastalığı (IVDH) sonucunda paraplejik kalan ve derin ağrı duyusu olmayan köpeklerde, nörona yönlendirilmiş kemik iliği kökenli otolog mezenşimal kök hücrelerin etkisini araştırmaktır.

YÖNTEM ve GEREÇLER: Bilinen tedavi yöntemleriyle nörolojik yönden herhangi bir gelişme kaydedilmeyen 7 köpek çalışmaya dahil edildi. Tüm köpeklerde manyetik rezonans görüntüleme (MRG) ile teşhis kondu ve operatif tedavi uygulandı. Her köpeğe 21 gün arayla toplam 2 kez olmak üzere, hemilaminektomi defektinden perkütan olarak omuriliğe; CNPase, MAP-2, GFAP ve beta III tubulin yönünden pozitif olan 5,0x10 ${ }^{6}$ nörona yönlendirilmiş kemik iliği kökenli otolog mezenşimal kök hücre süspansiyonu enjekte edildi.

BULGULAR: Hücre transplantasyonundan 2 ay sonra sadece 1 olguda yürüyüş skorunda 1 skor gelişme kaydedildi. Dördüncü ayda, 5 olguda yürüyüş skorunda 1 skor gelişme, 1 olguda ise nosisepsiyon ve propriosepsiyon değerlerinde 1 skor gelişme kaydedildi. Sekiz ay süreyle takip edilen 4 köpeğin; yürüyüş skorunda 3 olguda ilerleme izlenirken, propriosepsiyonda 2, nosisepsiyonda ise 3 olguda ilerleme kaydedildi.

SONUÇ: Bulgularımız, prognozu kötü olan IVDH' nda nörona yönlendirilmiş kemik iliği kökenli otolog mezenşimal kök hücre kullanımının umut verici bir yaklaşım yöntemi olduğunu önermektedir.

ANAHTAR SÖZCÜKLER: Omurilik hasarı, Köpek, Mezenkimal kök hücre, İntervertebral disk hastalığı 


\section{INTRODUCTION}

Spinal Cord Injury ( $\mathrm{SCl}$ ) is a common problem for humans and also companion animals. Even though the epidemiological data concerning the global prevalence of $\mathrm{SCl}$ is inaccessible, it is appraised that more than 130,000 humans suffer from $\mathrm{SCl}$ per year. Up to now, there is no cure available for these individuals, and unfortunately $\mathrm{SCl}$ usually leads to important life-long disability $(1,14)$.

Regenerative therapies based on stem cells have aroused considerable interest, and has leaded to promising results in a number of pre-clinical and clinical applications $(11,13)$. Numerous experimental studies have been reported with different success rates for $\mathrm{SCl}$, however they have not been fully translated into the benefit of patients, both human and also companion animal $(14,40)$. This can be related to many differences between models and clinical cases, including the ones encountered after naturally occurring spinal cord injury (14).

An experimental study has revealed that repair of the whole injured spinal cord area for functional recovery may not be necessary to allow walking; just restoring 10-15\% of connection in the spinal cord can be sufficient $(7,23)$. A better understanding of the pathophysiology of $\mathrm{SCl}$ has been attained in the early 1980s with neuroprotection, and has proceeded in the 1990s, and eventually the regenerative approach has become the main focus of investigators (40). Progress in understanding pathophysiology, acute trauma care, interventional surgery, spinal instrumentation, rehabilitation and regenerative medicine have come into a crucial level for spinal cord injury. This compromise encourages the investigators to search appropriate ways to cure this devastating disease which has impact on the emotional and physical well-being of affected individuals and the society (24).

The prognosis for functional recovery of thoracolumbar intervertebral disk disease is highly related to severity of internal injury to the spinal cord. Acute high velocity disk extrusions generally have a more guarded prognosis than the slow disk extrusions $(5,6)$. Poor clinical outcome is also associated with severe neurological deficits, especially the loss of deep pain perception (DPP) and the duration of its absence in hind limbs $(28,34)$. The naturally occurring disease is a crucial disease for translational medicine to human.

The purpose of this study is to report the results of the use of neurogenically-induced autologous bone marrow-derived mesenchymal stem cells (NIBM-MSCs) for naturally occurred spinal cord injury secondary to thoracolumbar disk extrusion causing paraplegia without DPP.

\section{MATERIAL and METHODS}

Client owned companion dogs with spinal cord injury located between T10- L4 vertebrae (the canine spinal cord has seven lumbar vertebra and terminates at the $L 5$ vertebra) secondary to IVD extrusion and paraplegia without DPP which is equivalent to thoracic ASIA (American Spinal Injury Association) ' $A$ ' for human patients were included in this study prospectively. The study protocol was approved by Ankara University ethical committee (2011-15-395), and informed consents were signed by the owners of each dog. In all cases, IVDD were diagnosed by MRI and were evaluated by electrophysiology. Dogs were underwent surgical treatment (hemilaminectomy, or hemilaminectomy and discectomy) following the diagnosis. Hemilaminectomy was carried out to do sequesterectomy (retrieving extruded disk materials from epidural space) and discectomy was carried out to remove degenerated nucleus pulposus from the intervertebral disc space. Bone marrow specimens were collected during operation in 6 dogs and before starting to physical therapy in one dog to produce stem cells. All dogs were treated by physical therapy following the surgery. All dogs were examined neurologically, no improvement detected dogs for at least 42 days after the initial injury (which is equivalent to about 6 months after injury in human patients) $(12,28)$ were included. This time period required for producing NIBM-MSCs was 42 days. In addition to aforementioned criteria, the cases followed at least 6 months were included in this study.

\section{Neurological Evaluation}

Texas spinal cord injury score (TSCIS) was conducted to evaluate the neurologic score at the admitted time and also outcomes. The gait score: no voluntary movement seen when the dog is supported score " 0 ", intact limb protraction with no ground clearance " 1 ", intact limb protraction with inconsistent ground clearance " 2 ", intact protraction with ground clearance $>75 \%$ of steps " 3 ", ambulatory with consistent ground clearance and significant paresis-ataxia that results in occasional falling " 4 ", ambulatory with consistent ground clearance and mild paresis-ataxia that does not result in falling " 5 " and normal gait " 6 ". Pelvic limb proprioception score: absent " 0 ", delayed " 1 " (correction occurred $>1$ second after positioning), and present "2". Pelvic nociception score: absent " 0 ", deep nociception only present " 1 ", or both deep and superficial nociception present " 2 " (21).

\section{Magnetic Resonance Imaging}

All of the MRI and electrophysiological procedures were carried out under medetomidine hydrochloride $(40 \mu \mathrm{g} / \mathrm{kg}$ i.m., Pfizer, USA) and ketamine hydrochloride $(5 \mathrm{mg} / \mathrm{kg}$, Interhas, Turkey). The images of all cases were obtained with an MRI unit (Superconducting magnet, field strength of 1.5 tesla, Siemens AG, Germany), using spinal coil. T1 weighted images (TR: $370-700 \mathrm{~ms}$, TE: $15-20 \mathrm{~ms}$ ) and T2 weighted images (TR: 2000-4000 ms, TE: $90-110 \mathrm{~ms}$ ) were adjusted as $2 \mathrm{~mm}$ slice thickness. Gadolinium diethylene-triaminepentaacetic acid (Magnevist, Bayer ${ }^{\oplus}$, Istanbul, Turkey) was used as the paramagnetic contrast medium, and was intravenously administered at a dose of $0.2 \mathrm{mmole} / \mathrm{kg}$.

\section{Electrophysiological Examination}

Somatosensory evoked potentials were studied under the same general anesthesia protocol. Briefly, tibial nerve was 
stimulated from the popliteal fossa and the potentials were recorded from two segments cranial and two segments caudal of the lesion by the hypodermic stainless steel needle. The recording needles were placed as: active electrode inserted near to the arcuate ligament and reference electrode inserted subfascially about $2 \mathrm{~cm}$ laterally over the paraspinal muscles. The ground electrode was inserted subcutaneously between the stimulating and recording electrodes. SEP was recorded from the scalp and 250 responses were averaged. Rating the injury potentials in posttraumatic SEP recordings was evaluated as:

0 : isoelectric line, 1: major deformation, uncertain response, 2: complete injury potential, 3 : incomplete injury potential, 4 : morphological change, 5: normal response (35).

Motor evoked potentials were recorded after magnetic stimulation two segments caudally and two segments cranially from the injury site using Double $70 \mathrm{~mm}$ Remote Control Coil (Magstim 200, the Magstim Company Ltd, UK) and the potentials were recorded from the gastrocnemius muscle in both sides.

\section{Isolation and Culture of BM-MSCs}

Bone marrow was collected from the iliac crest and transported to the laboratory within an hour. BM-MSCs were cultured according to standard methods $(4,27)$. Under sterile conditions, $\sim 5-10 \mathrm{ml}$ of marrow suspended in a-MEM (Hyclone, Uppsala, Sweden) containing $1 \%$ penicillin-streptomycin (Pen/Strep) and 2 mM L-glutamine (L-Glu; Sigma, St. Louis, $\mathrm{MO}$, USA) was washed thrice in 0.1 M PBS with sequential centrifugation (at $25^{\circ} \mathrm{C}$ and $1000 \mathrm{rpm}$ ). Subsequently, the cells were seeded into tissue culture flasks containing a-MEM supplemented with Pen/Strep, L-Glu, and $10 \%$ fetal bovine serum (Lonza, Basel, Switzerland) at $37^{\circ} \mathrm{C}$ with humidified $5 \% \mathrm{CO}_{2}$. The non-adherent cells were removed by replacing the medium on the second day of subculture. The cells were cultured up to passage 2 under the same conditions, with medium changes every other day. At this point, $\sim 5.0 \times 10^{6}$ BM-MSCs were separated and induced into the neurogenic lineage. The remaining BM-MSCs were cultured likewise for the subsequent booster application.

\section{In Vitro Neurogenic Differentiation of BM-MSCs}

BM-MSCs were induced into the neurogenic lineage by a two-step differentiation protocol (22). Briefly, cells were placed in tissue culture flasks coated with poly(hydroxyethyl methacrylate) (Sigma) and cultured in the B-27 and N-2 containing neurobasal medium (MesenPro ${ }^{\mathrm{TM}}$ with $10 \%$ MesenPro $^{\text {TM }}$ supplement, Pen/Strep, and L-Glu; Invitrogen), supplemented with $100 \mathrm{ng} / \mathrm{ml}$ epidermal growth factor (EGF) and $10 \mathrm{ng} / \mathrm{ml}$ basic fibroblast growth factor (bFGF) (Millipore, MA, USA). The resulting neurospheres were histologically stained to confirm positivity to Nestin (Santa Cruz).

At the second step, the acquired neurospheres were disaggregated by accutase (Gibco, NY, USA) and the cell suspension was plated in tissue culture flasks which were coated with poly(ornithine) (Sigma). The neurosphere-derived cell suspension was then cultured for six days in the neurobasal medium supplemented with $100 \mathrm{ng} / \mathrm{ml}$ nerve growth factor (NGF) and $10 \mathrm{ng} / \mathrm{ml}$ brain-derived neurotrophic factor (BDNF) (Millipore) for further induction into the neurogenic lineage. At $\sim 80 \%$ confluence, the cells were removed from the surface by $0.05 \%$ Trypsin $/ 0.53 \mathrm{mM}$ EDTA solution (Sigma), washed thrice with PBS, and $1 \mathrm{ml}$ of cell suspension was transferred into a syringe and delivered to the surgery room within $\sim 30$ minutes. Immunohistochemistry revealed that these cells were positive to CNPase and MAP-2, as well as to GFAP and beta III tubulin (Abcam).

\section{Cell Transplantation Procedure}

Under general anesthesia as provided for taking MRI, about $5.0 \times 10^{6}$ NIBM-MSCs suspended in $1.0 \mathrm{ml}$ of PBS were injected through the hemilaminectomy defect intraspinally at three different points. The right location of the needle tip was verified by the appearance of the cerebrospinal fluid coming from the needle, and directed into the spinal cord parenchyma. The cell transplantation procedure $\left(\sim 5.0 \times 10^{6}\right.$ NIBM-MSCs) was repeated after 21-days.

\section{Physical Therapy}

Active range of motion, massage to the hindlimbs, warming thoracolumbar spine, forcing the dog to stand and walk its hindlimbs with bellyband was proposed to the owners up to the processing collected bone marrow and also after transplantation.

\section{RESULTS}

Seven cases were matched with case selection criteria. Six cases were admitted for the first time (1-2 days), and one case that was operated 4 months before, but neurological improvement not attained were included in this study. The overall data are presented in Table I. The mean age at presentation was 5.79 years (range, 2.5-13 years). Breeds included poodle $(n=2)$, pekingese $(n=2)$, French bulldog $(n=2)$ and mixed breed $(n=1)$. Sex dispersion was 5 males and 2 females. The time from the beginning of clinical signs up to the admission was about 3 days in 5 cases, progressive paraparesis for 6 months and resulted in paraplegia for 1 week in one case, no progression in neurological status in one case which underwent surgery 4 months previously (case no:3 in Table I). MRI were taken from all dogs at the day of clinical examination, and they were operated the day after the admission in 6 dogs. One dog was not operated because of any signs of compression at the operated area or adjacent sites, and he was treated by physical therapy after bone marrow collection.

The MRI of the dogs which were presented at the first time for surgical treatments revealed disk extrusion at different locations (Figure 1,2), as seen in Table I and it was also accompanied with type 2 disk disease in four cases. One case which had been operated before for type one disk extrusion and failed to improve had epidural fibrosis at the 


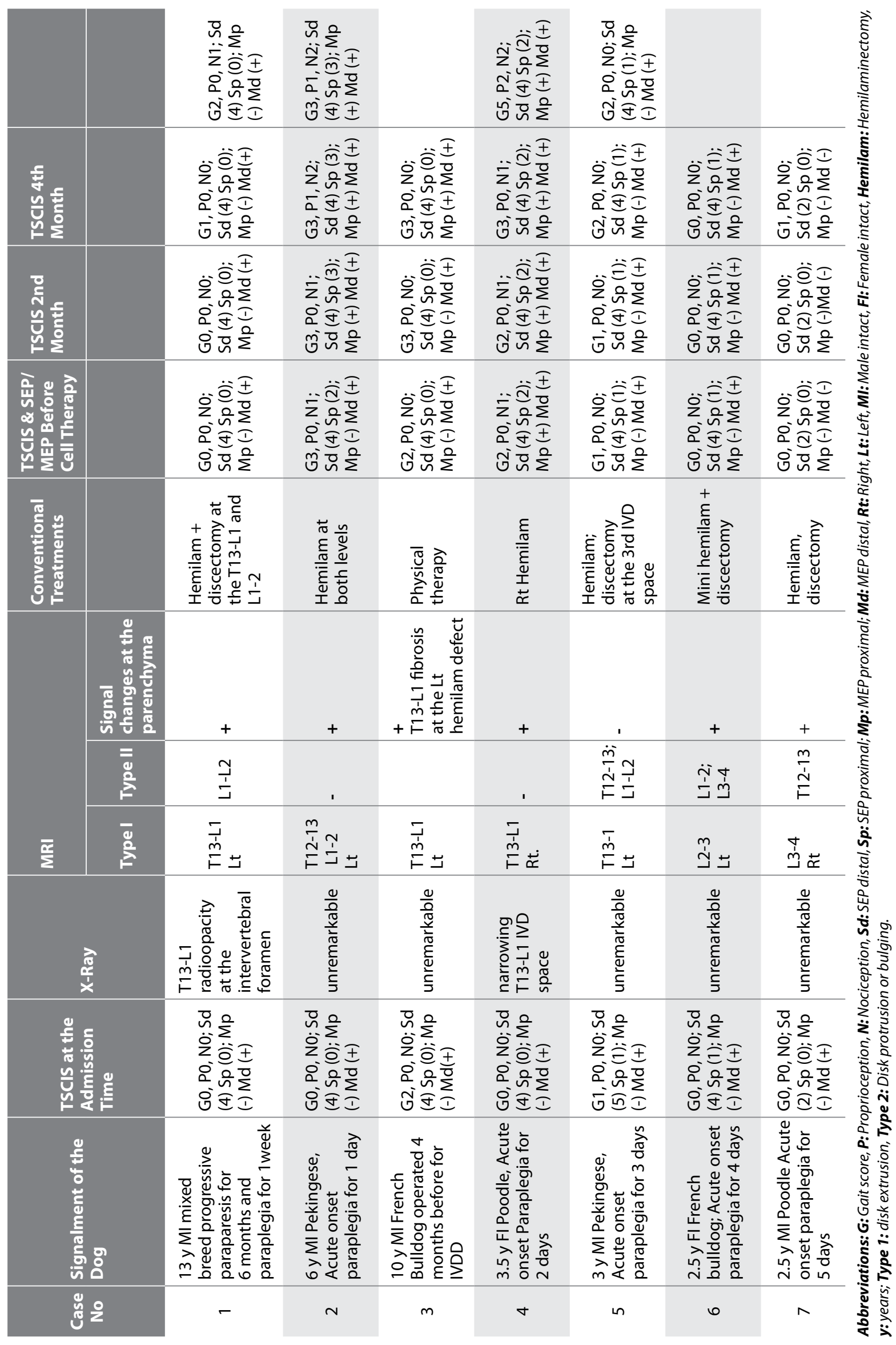




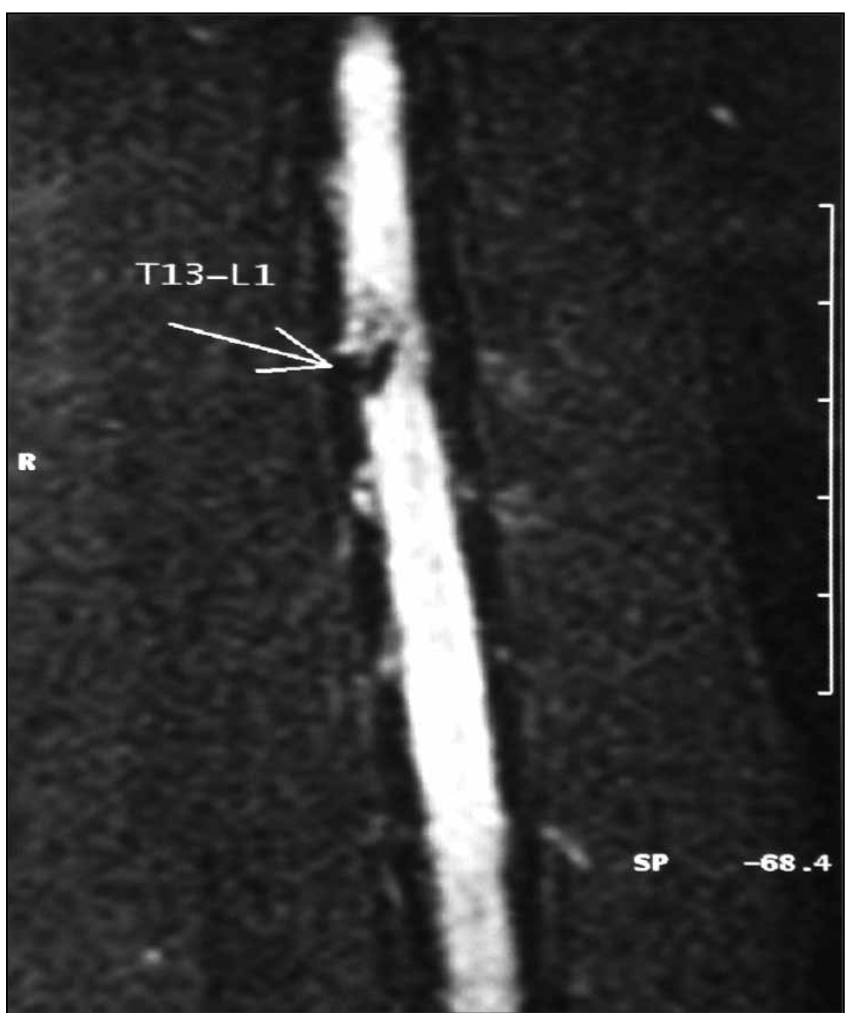

Figure 1: Coronal T2W image of the T13-L1 disk extrusion.

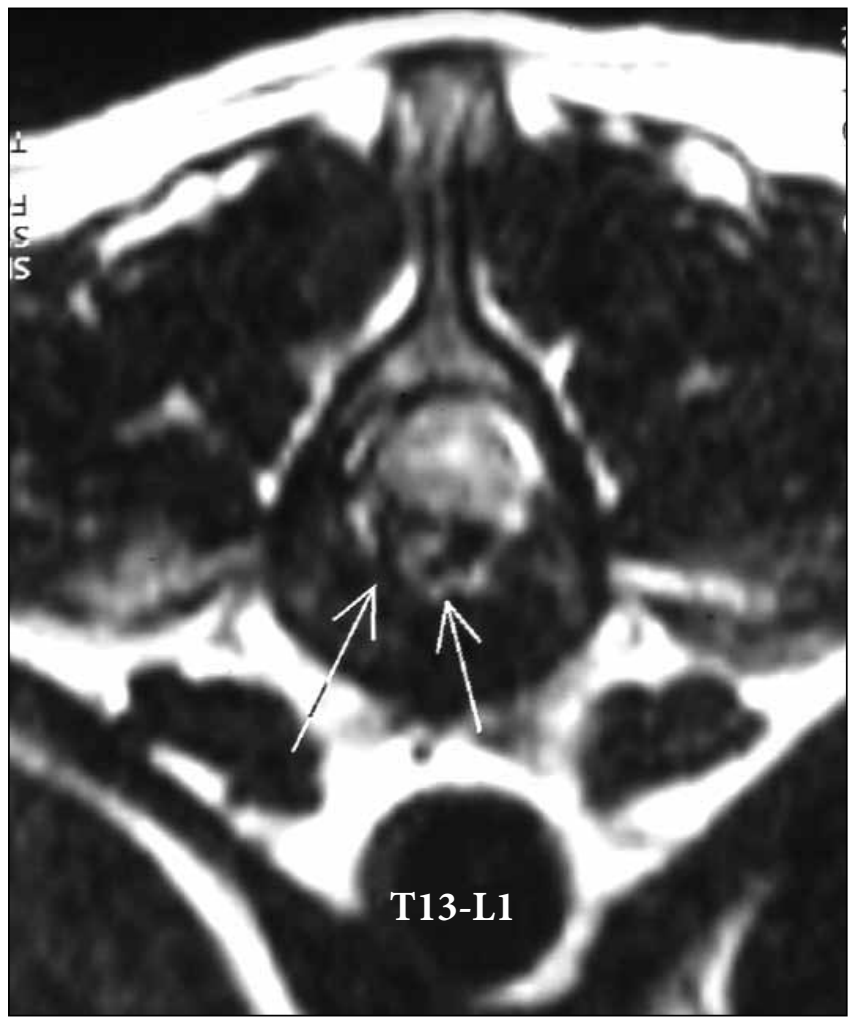

Figure 2: Axial T2 W image of the T13-L1 disk extrusion. hemilaminectomy defect. All cases had hyperintense lesions in T2 $\mathrm{w}$ images in the spinal cord.

The gait score before treatment was 0 in 5 cases, 2 in 1 case and 1 in one case. Proprioception and nociception score were 0 in all cases. After the surgical and physical treatment $(n=6)$, and just physical treatments $(n=1)$ for 42 days, which is the time period for cell processing: gait score had improved in 1 case as 3 ( 0 to 3 ), and 2 ( 0 to 2 ) scores in 1 case, and the rest were at the same score. Proprioception score was not changed in any case, however nociception had improved one score in 2 of the cases.

Two months after cell transplantation, there were no changes except for 1 gait score improvement for 1 of the cases. At the 4th month, gait score had improved one score in 5 cases, and 1 score progress was recorded in proprioception and nociception in one case. In eight months-followed up 4 cases were evaluated by the same parameter; gait score had improved in 3 cases (one score in 1, two scores in 1, and three score in 1), and proprioception improved 1 and 2 scores for each in 2 cases, and nociception improved in 3 cases as one score in 2 cases and two scores in 1 case.

SEP and MEP: The details of the results are introduced in Table I. One case showed improvement in both SEP and MEP as normal, and one case improved in MEP after cell transplantation.

\section{DISCUSSION}

Overall, the results of this study show some beneficial effect of intraspinal injection of autologous NIBM-MSCs in dogs with paraplegia without DPP secondary to thoracolumbar IVD extrusion. The prognosis of the dogs in this grade is poorest and they are equivalent to thoracal ASIA " $A$ " in humans (23). Even though spontaneous improvement in this grade has been reported, they are at the lowest level among the spinal cord injuries in canine practice, and the hopeless cases have been selected for this study consciously. Small gains are acceptable for those kind of dogs as very crucial. To the best of our knowledge, this is the first study evaluating the beneficial effects of autologous NIBM-MSCs in chronic and unfavorable prognosis spinal cord injury after IVDD in dogs. The results of this study may also have potential contribution for translation to human thoracal spinal cord injury.

Bone marrow-derived stem cells can differentiate into glial cells or neurons that may improve the effects of regenerative therapy in spinal cord injury $(26,33)$. The best therapeutic outcomes can be achieved with optimal dosage, timing and their administration route (36). As MSCs can be expanded and differentiated into the neurogenic lineage through neurospheres in vitro, before being transplanted back, they may prove to be more beneficial for treating $\mathrm{SCI}$ (10). Because of the hopeless results of spinal cord injury, the best method possible as inferred from the experimental studies has been applied to this cohort of clinical cases.

Usage of MSCs has been examined in many studies for acute or chronic injury models of the spinal cord. In both models, MSCs 
have been shown to promote significant functional recovery $(15,37,39)$. The percutaneous transplantation technique (19) preferred in this study, is minimally invasive, reliable, and easily applicable and does not require advanced level of experience. Especially in case of non-obesity, the hemilaminectomy defect can be felt by palpation as absence of articular processes. However in obese cases, the operated area can be guessed by the presence of scar in skin. Percutaneous insertion of the spinal needle into the subarachnoid space can be confirmed by the leakage of cerebrospinal fluid, and can be progressed into the spinal cord parenchyma. It was found easier than collecting CSF from L5-6 spinal tapping. Intraspinal injection as the cell delivery method was used in all cases presented in this study.

The use of different stem cell types including MSCs from the umbilical cord blood, Wharton's jelly, adipose and bone marrow $(20,32)$ as well as embryonic stem cells $(24)$ and oligodendrocytes, Schwann cells (29) and olfactory glial cells (16) have shown distinct rates of success. The spinal cord ependymal layer and periependymal region have become focus of interest in $\mathrm{SCl}$ research because of the potential for this region to serve as an endogenous source of neural stem cells to aid in tissue regeneration and repair (26). Many attempts have been made by researchers to clarify the side effects of allogeneic stem cell transplantation. Even though autologous MSCs transplantation has shown more beneficial effects than that of allogeneic MSCs transplantation, allogeneic MSCs transplantation has also been effective in improving functional recovery following $\mathrm{SCl}(17,38)$. In this study, we have used autologous NIBM-MSCs for their known safety, following collecting, processing and neurogenic differentiation. Main limitation of using autologous NIBMMSCs was found to be the required period of time and the high cost.

A recent study (31) reports the use of autologous BM-MSCs by administration (after exposing the operated area) into the spinal cord of 4 dogs with chronic spinal cord injury secondary to IVDD, and improvement in 3 dogs after 18 months follow up was noted. Neurological score of those cases are not so different from ours; while we have used the minimal invasive delivery method of autologous NIBM-MSCs, and have obtained some hopeful improvements.

In an experimental canine model of spinal cord injury, it was indicated that the use of neural-induced allogeneic MSC transplantation together with Matrigel revealed functional improvement 1 week after $\mathrm{SCl}$. Findings were explained by neurotrophic effects, including neurotrophin production and decreased inflammation and astrogliosis, as well as increased neuronal extension and regeneration (30). The presented cases in this study had also failed with conventional treatments, and there was no improvement until about 42 days after hemilaminectomy and retrieving extruded disk materials from the epidural space. Because of early beneficial effect of cell therapy which is confirmed in experimental studies, we preferred to transplant the cells 2 times with 21 days interval to sustain this possible effect for a longer period, and follow up longer time for the outcomes. When the clinical and electrophysiological results of these cases recorded before cell transplantation with the 2 months results, there were no remarkable changes. The beneficial effects of cell therapy at the early period in these clinical cases that had chronic spinal cord injuries (more than 45 days) have not been seen. However, the use of BM-MSCs for SCl injury has revealed remyelination and neuroprotection from releasing cytokines in experimentally induced spinal cord injuries in rat models $(2,9)$. The time required for preparing autologous NIBM-MSCs is relatively long and it is not possible to deliver these cells at the acute stage of spinal cord injury. Solving the time limitation and some additional treatment modalities should be considered to provide a better environment for cells to assure better outcomes in chronic spinal cord injury.

The success rate of thoracolumbar disk disease, absent of DPP cases admitted longer than $24 \mathrm{~h}$, was found $10 \%$ in a case series (18). In another study for the cases at the same neurologic status; sixty-four of 70 dogs with intervertebral disk herniation had underwent surgery; $9(14 \%)$ were euthanized within 3 weeks after surgery (7 related to ascending myelomalacia), $37(58 \%)$ regained DPP and the ability to walk, $7(11 \%)$ regained the ability to walk without regaining DPP, and $11(17 \%)$ remained paraplegic without DPP (28). The previous report's success rate ranges from $0 \%$ to $76 \%(3,8,5,34)$.

Comparing recovery rates of different studies is complicated, because of many variables as case selection criteria, the duration of DPP absence, loss of motor function, and the applied treatment modality. When the results of this study are compared with the literature, the rate of success is not dramatically different. However the improvement in nociception and proprioception can be accepted as crucial for carrying out further investigation in this area, in higher number of cases with certain criteria.

In conclusion, percutaneous intraspinal injection of autologous NIBM-MSCs in dogs with paraplegia, lacking DPP after IVDD which has poor prognosis, and failed with conventional therapy provide some clinical benefits. The minimal invasive administration technique applied in this study was found to be simple and a reliable method for cell therapy without any complication.

\section{ACKNOWLEDGMENTS}

This study was supported by The Scientific and Technological Research Council of Turkey (TUBITAK; grant number 1110428). YM Elcin acknowledges the support of the Turkish Academy of Sciences (TÜBA, Ankara, Turkey).

\section{REFERENCES}

1. Aghayan HR, Arjmand B, Yaghoubi M, Moradi-Lakeh M, Kashani $H$, Shokraneh F: Clinical outcome of autologous mononuclear cells transplantation for spinal cord injury; A systematic review and meta-analysis. Med J Islam Repub Iran 28: 112-120, 2014 
2. Akiyama Y, Radtke C, Kocsis JD: Remyelination of the rat spinal cord by transplantation of identified bone marrow stromal cells. J Neurosci 22: 6623-6630, 2002

3. Anderson SM, Lippincott $\mathrm{CL}$, Gill PJ: Hemilaminectomy in dogs without deep pain perception. California Vet 45: 24-28, 1991

4. Baykan E, Koc A, Elcin AE, Elcin YM: Evaluation of a biomimetic poly ( $\varepsilon$-caprolactone) $/ \beta$ tricalcium phosphate multispiral scaffold for bone tissue engineering: In vitro and in vivo studies. Biointerphases 9(2): 029011, 2014

5. Besalti O, Ozak A, Pekcan Z, Tong S, Eminaga S, Tacal T: The role of extruded disk material in thoracolumbar intervertebral disk disease: A retrospective study in 40 dogs. Can Vet J 46(9): 814, 2005

6. Besalti O, Pekcan Z, Sirin YS, Erbas G: Magnetic resonance imaging findings in dogs with thoracolumbar intervertebral disk disease: 69 cases (1997-2005). J Am Vet Medl Assoc 228(6): 902-908, 2006

7. Blight AR: Cellular morphology of chronic spinal cord injury in the cat: Analysis of myelinated axons by line-sampling. Neuroscience 10: 521-543, 1983

8. Brown NO, Helphrey ML, Prata RG: Thoracolumbar disk disease in the dog: A retrospective analysis of 187 cases. J Am Anim Hosp Assoc 13: 665-672, 1977

9. Chopp M, Zhang XH, Li Y, Wang L, Chen J, Lu D, Lu M, Rosenblum M: Spinal cord injury in rat: Treatment with bone marrow stromal cell transplantation. Neuroreport 11: 30013005,2000

10. Chung WH, Park SA, Lee JH, Chung DJ, Yang WJ, Kang EH, Choi CB, Chang HS, Kim DH, Hwang SH, Han H, Kim HY: Percutaneous transplantation of human umbilical cordderived mesenchymal stem cells in a dog suspected to have fibrocartilaginous embolic myelopathy. J Vet Sci 14(4): 495497, 2013

11. Elcin YM (ed). Tissue engineering, stem cells, and gene therapies. Vol. 534. Springer US: Springer Science \& Business Media, 2003: 1-340

12. Fawcett JW, Curt A, Steeves JD, Coleman WP, Tuszynski MH, Lammertse D, Bartlett, PF, Blight AR, Dietz V, Ditunno, J: Guidelines for the conduct of clinical trials for spinal cord injury as developed by the ICCP panel: Spontaneous recovery after spinal cord injury and statistical power needed for therapeutic clinical trials. Spinal Cord 45: 190-205, 2007

13. Fehlings MG, Vawda R: Cellular treatments for spinal cord injury. The time is right for clinical trials. Neurotherapeutics 8(4): 704-720, 2011

14. Granger N, Blamires H, Franklin RJ, Jeffery ND: Autologous olfactory mucosal cell transplants in clinical spinal cord injury: A randomized double-blinded trial in a canine translational model. Brain 135(11): 3227-3237, 2012

15. Hyatt AJ, Wang D, van Oterendorp C, Fawcett JW, Martin KR: Mesenchymal stromal cells integrate and form longitudinallyaligned layers when delivered to injured spinal cord via a novel fibrin scaffold. Neuroscience Letters 569: 12-17, 2014
16. Jeffery ND, Lakatos A, Franklin RJ: Autologous olfactory glial cell transplantation is reliable and safe in naturally occurring canine spinal cord injury. J Neurotrauma 22: 1282-1293, 2005

17. Jung DI, Ha J, Kang BT, Kim JW, Quan FS, Lee JH, Park HM: A comparison of autologous and allogenic bone marrowderived mesenchymal stem cell transplantation in canine spinal cord injury. J Neurol Sci 285(1): 67-77, 2009

18. Laitinen OM, Puerto DA: Surgical decompression in dogs with thoracolumbar intervertebral disc disease and loss of deep pain perception: A retrospective study of 46 cases. Acta Vet Scand 46(1-2): 79-85, 2005

19. Lee JH, Chang HS, Kang EH, Chung DJ, Choi CB, Lee JH, Hwang $\mathrm{SH}$, Han H, Kim HY: Percutaneous transplantation of human umbilical cord blood-derived multipotent stem cells in a canine model of spinal cord injury. J Neurosurg Spine 11: 749-757, 2009

20. Lee JH, Chung WH, Kang EH, Chung DJ, Choi CB, Chang HS, Kim HY: Schwann cell-like remyelination following transplantation of human umbilical cord blood (hUCB)derived mesenchymal stem cells in dogs with acute spinal cord injury. J Neurol Sci 300(1-2): 86-96, 2011

21. Levine GJ, Levine JM, Budke CM, Kerwin SC, Au J, Vinayak A, Hettlich BF, Slater MR: Description and repeatability of a newly developed spinal cord injury scale for dogs. Prev Vet Med 89(1-2): 121-127, 2009

22. Lim JH, Boozer L, Mariani CL, Piedrahita JA, Olby NJ: Generation and characterization of neurospheres from canine adipose tissue-derived stromal cells. Cell Reprogram 12(4): 417-425, 2010

23. McDonald JW: Repairing the damaged spinal cord: From stem cells to activity-based restoration therapies. Clinical Neurosurgery 51: 207-227, 2003

24. McDonald JW, Liu XZ, Qu Y, Liu S, Mickey SK, Turetsky D, et al: Transplanted embryonic stem cells survive, differentiate and promote recovery in injured rat spinal cord. Nat Med 5: 1410-1412, 1999

25. Moore SA, Oglesbee MJ: Spinal cord ependymal responses to naturally occurring traumatic spinal cord injury in dogs. Vet Pathol 2014, (Epub ahead of print)

26. Muñoz-Elías G, Woodbury D, Black IB: Marrow stromal cells, mitosis, and neuronal differentiation: Stem cell and precursor functions. Stem Cells 21: 437-448, 2003

27. Odabas $\mathrm{S}$, Elcin $\mathrm{AE}$, Elcin $\mathrm{YM}$ : Isolation and characterization of mesenchymal stem cells. Method Mol Biol 1109: 47-63, 2014

28. Olby N, Levine J, Harris T, Muñana K, Skeen T, Sharp N: Longterm functional outcome of dogs with severe injuries of the thoracolumbar spinal cord: 87 cases (1996-2001). J Am Vet Med Assoc 222: 762-769, 2003

29. Oudega M: Schwann cell and olfactory ensheathing cell implantation for repair of the contused spinal cord. Acta Physiol 189: 181-189, 2007

30. Park SS, Lee YJ, Lee SH, Lee D, Choi K, Kim WH, Han HJ: Functional recovery after spinal cord injury in dogs treated with a combination of Matrigel and neural-induced adiposederived mesenchymal stem cells. Cytotherapy 14(5): 584-597, 2012 
31. Penha EM, Meira CS, Guimarães ET, Mendonça MVP, Gravely FA, Pinheiro CMB, Pinheiro TMB, Barroin-Melo SM, Ribeirodos-Santos R, Soares MBP: Use of autologous mesenchymal stem cells derived from bone marrow for the treatment of naturally injured spinal cord in dogs. Stem Cells International February 2014; 8. Available from: Hindawi Publishing Corporation. Accessed February 15, 2015

32. Ryu HH, Kang BJ, Park SS, Kim Y, Sung GJ, Woo HM, Kim WH, Kweon OK: Comparison of mesenchymal stem cells derived from fat, bone marrow, Wharton's jelly, and umbilical cord blood for treating spinal cord injuries in dogs. J Vet Med Sci 74(12): 1617-1630, 2012

33. Sanchez-Ramos J, Song S, Cardozo-Pelaez F, Hazzi C, Stedeford T, Willing A, Freeman TB, Saporta S, Janssen W, Patel N, Cooper DR, Sanberg PR: Adult bone marrow stromal cells differentiate into neural cells in vitro. Exp Neurol 164: 247-256, 2000

34. Scott HW, McKee WM: Laminectomy for 34 dogs with thoracolumbar intervertebral disc disease and loss of deep pain perception. J Small Anim Pract 40(9): 417-422, 1999
35. Sirin YS, Keles H, Besalti O, Atalay Vural S: Comparison of ATP$\mathrm{MgCl} 2$ and methylprednisolone in experimentally induced spinal cord trauma. J Clin Anal Med 3(4): 442-447, 2012

36. Tohda C, Kuboyama T: Current and future therapeutic strategies for functional repair of spinal cord injury. Pharmacology \& Therapeutics 132 (1): 57-71, 2011

37. Vaquero J, Zurita M, Oya S, Santos M: Cell therapy using bone marrow stromal cells in chronic paraplegic rats: Systemic or local administration? Neurosci Lett 398(1-2): 129-134, 2006

38. Willing $A E$, Lixian J, Milliken M, Poulos S, Zigova T, Song $S$, Hart C, Sanchez-Ramos J, Sanberg PR: Intravenous versus intrastriatal cord blood administration in a rodent model of stroke. Journal of Neuroscience Research 73: 296-307, 2003

39. Wu S, Suzuki Y, Ejiri Y, Noda T, Bai H, Kitada M, Kataoka K, Ohta $\mathrm{M}$, Chou $\mathrm{H}$, Ide C: Bone marrow stromal cells enhance differentiation of cocultured neurosphere cells and promote regeneration of injured spinal cord. J Neurosci Res 72(3): 343-351, 2003

40. Yilmaz T, Kaptanoglu E: Current and future medical therapeutic strategies for the functional repair of spinal cord injury. World Journal of Orthopedics 6(1): 42-55, 2015 